\title{
Evaluating the Importance of Innovative Heterogeneous Chemistry to Explain Observed Stratospheric Ozone Depletion
}

\author{
D.E. Kinnison \\ P.S. Connell
}

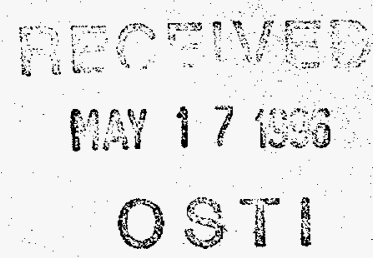

February 1996

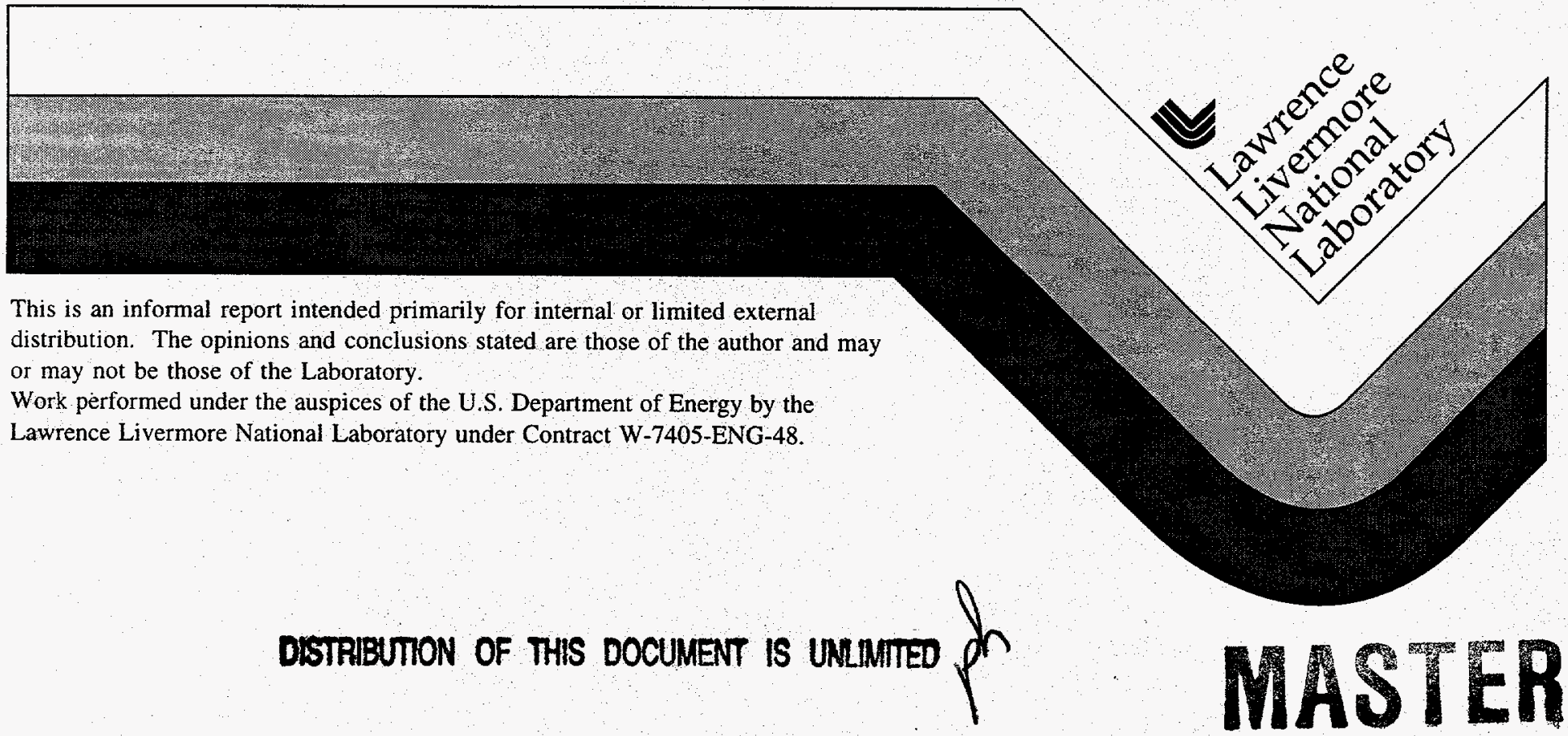




\section{DISCLAIMER}

This document was prepared as an account of work sponsored by an agency of the United States Government. Neither the United States Government nor the University of California nor any of their employees, makes any warranty, express or implied, or assumes any legal liability or responsibility for the accuracy, completeness, or usefulness of any information, apparatus, product, or process disclosed, or represents that its use would not infringe privately owned rights. Reference herein to any specific commercial product, process, or service by trade name, trademark, manufacturer, or otherwise, does not necessarily constitute or imply its endorsement, recommendation, or favoring by the United States Government or the University of California. The views and opinions of authors expressed herein do not necessarily state or reflect those of the United States Government or the University of California, and shall not be used for advertising or product endorsement purposes.

This report has been reproduced directly from the best available copy.

Available to DOE and DOE contractors from the Office of Scientific and Technical Information P.O. Box 62, Oak Ridge, TN 37831

Prices available from (615) 576-8401, FTS 626-8401

Available to the public from the National Technical Information Service

U.S. Department of Commerce 5285 Port Royal Rd. Springfield, VA 22161 


\section{DISCLAMMER}

Portions of this document may be illegible in electronic image products. Images are produced from the best available original document. 


\title{
Evaluating the Importance of Innovative Heterogeneous Chemistry to Explain Observed Stratospheric Ozone Depletion
}

\author{
Douglas E. Kinnison and Peter S. Connell \\ Atmospheric Science Division \\ Lawrence Livermore National Laboratory \\ P.O. Box 808, L-240
}

February 27, 1996

Laboratory Directed Research and Development

Final Report for 93-ERD-041 


\begin{abstract}
In re-analyzing total ozone data from a NASA satellite for the period 1978-1990 (Stolarski et al. 1991) found unexpectedly high ozone reductions at mid to high-latitudes of both hemispheres, for example a $8 \%$ ozone reduction at $60^{\circ} \mathrm{N}$ between 1980 and 1990 . The Junge layer of particulates in the lower stratosphere is composed primarily of super-cooled liquid sulfuric acid with dissolved water and trace amounts of other species. Rodriquez et al. [1991] demonstrated with model calculations that the heterogeneous reaction of $\mathrm{N}_{2} \mathrm{O}_{5}$ with water in sulfate aerosols may contribute to the high ozone reductions at midlatitudes. Recently, the 15 June 1991 volcanic eruption of Mt. Pinatubo resulted in large amounts of sulfur containing particles in the stratosphere. Complete conversion of $\mathrm{SO}_{2}$ to $\mathrm{H}_{2} \mathrm{SO}_{4}$ aerosols occurred within a few months after the eruption. Balloon sondes and satellite data suggest that stratospheric ozone decreased 6-10\% in the tropics by October 1991. Ground based measurements along with ozone sonde and satellite measurements show above average loss of ozone in 1992 and 1993. Currently, there is a widespread search for additional heterogeneous reactions or combination of heterogeneous and homogeneous (gas-phase) reactions that could catalytically reduce ozone to observed levels.
\end{abstract}

Burley and Johnston [1992a,b], of the University of California at Berkeley, proposed that nitrosyl sulfuric acid (NSA) $\mathrm{NOHSO}_{4}$, is a promising heterogeneous reactant for activating $\mathrm{HCl}$ in sulfuric acid particles. They list several sources for producing it in the stratosphere and they carried out thermodynamic and chemical kinetic calculations at one stratospheric altitude and at one latitude. NSA has been overlooked in all previous stratospheric model calculations, even though it has been observed in stratospheric sulfate aerosols (Farlow et al. 1978). This study makes large scale atmospheric model calculations to test the proposal by Burley and Johnston [1992a,b] that a promising heterogeneous process for activating $\mathrm{HCl}$ in sulfuric acid particles is a catalytic couple based on nitrosyl sulfuric acid (NSA). This mechanism would convert $\mathrm{HCl}$, which is a reservoir species for chlorine free radicals, into a form that catalytically reduces ozone. These calculations used the LLNL 2-D zonally averaged chemical-radiative-transport model of the troposphere and stratosphere.

These calculations set firm limits on the range of kinetic parameters over which this heterogeneous reaction would be important in the global ozone balance, and thus be a guide for where laboratory work is needed. 


\section{INTRODUCTION}

In 1985, atmospheric modelers using the Rowland-Molina theory of ozone destruction by CFCs predicted that continued use of CFCs at the 1980 production rate would, within 100 years, lead to $3 \%$ steady-state global ozone reduction with maximum local ozone reduction occurring at about $40 \mathrm{~km}$ altitude [WMO 1986, Chapter 13]. Also in 1985, Farman et al. reported that they had measured 30\% ozone reduction of total ozone during the Antarctic springtime for the 19801984 period relative to 1957-73. A variety of new hypotheses were formulated during 19861987 to explain these totally unexpected results. During the Antarctic spring of 1987, NASA carried out a major measurements campaign using ground based instruments, heavily instrumented aircraft and satellites, and they observed widespread 50\% reductions of the ozone column with maximum local reductions below $20 \mathrm{~km}$ altitude. The major features of the "Antarctic ozone hole" were explained by 1989 on the basis of atmospheric observations, new theories, and new laboratory experiments on heterogeneous reaction occurring at low temperatures on ice particles [WMO 1989]. In the standard models, virtually all active chlorine species $(\mathrm{Cl}, \mathrm{ClO})$ in the lower stratosphere, especially in the low polar stratosphere, were tied up as inactive chlorine nitrate $\left(\mathrm{ClONO}_{2}\right)$ or hydrogen chloride $(\mathrm{HCl})$. As a result of this new information, models have been updated to allow $\mathrm{ClONO}_{2}$ and $\mathrm{HCl}$ to react on the solid surface of polar stratospheric clouds to form inactive nitric acid $\left(\mathrm{HNO}_{3}\right)$ and to release readily photolyzed products such as molecular chlorine $\left(\mathrm{Cl}_{2}\right)$ and hypochlorous acid $(\mathrm{HOCl})$.

In re-analyzing total ozone data from a NASA satellite for the period 1978-1990 (Stolarski et al. 1991) found unexpectedly high ozone reductions at mid to high-latitudes of both hemispheres, for example a $8 \%$ ozone reduction at $60^{\circ} \mathrm{N}$ between 1980 and 1990 . These depletions were at latitudes where polar heterogeneous chemistry was not applicable. The Junge layer of particulates in the lower stratosphere is composed primarily of super-cooled liquid sulfuric acid with dissolved water and trace amounts of other species. Hofmann and Solomon [1989] proposed that they may play a role in global ozone chemistry. Rodriquez et al. [1991] demonstrated with model calculations that the heterogeneous reaction of $\mathrm{N}_{2} \mathrm{O}_{5}$ with water in sulfate aerosols may contribute to the high ozone reduction at midlatitudes.

Mt. Pinatubo erupted on 15 June 1991, injecting the largest amount of $\mathrm{SO}_{2}$ into the stratosphere during this century. Within a couple month after the eruption, $\mathrm{SO}_{2}$ is completely converted to $\mathrm{H}_{2} \mathrm{SO}_{4}$. There has been a large effort to monitor by satellite, aircraft, balloon 
sondes, and ground based instruments the chemical species that control ozone formation and loss during this period. Similar to the situation in the mid-1980s, model-derived trends in ozone following the Mt. Pinatubo erupition can not fully explain the observed measurements. Currently, there is a widespread search for additional significant heterogeneous reactions on and within the sulfate aerosols to explain the observations.

\section{OBJECTIVE}

This study is an effort to make large scale atmospheric model calculations to test the proposal by Burley and Johnston [1992a,b] that a promising heterogeneous process for activating $\mathrm{HCl}$ in sulfuric acid particles is a catalytic couple based on nitrosyl sulfuric acid (NOHSO 4 or NSA). This mechanism would convert $\mathrm{HCl}$, which is a reservoir species for chlorine free radicals, into a form that catalytically reduces ozone. This mechanism is examined under nonvolcanic and volcanic conditions representative of the recent eruption of Mt. Pinatubo. Our calculations set firm limits on the range of kinetic parameters over which this heterogeneous processes would be important in the global ozone balance, and thus is a guide for where laboratory work is needed. In addition, we have derived a preliminary time-dependent integration (1980-1994) to represent the observed trend in ozone. Comparison between modelderived and observed ozone trend will be compared.

\section{LLNL 2-D MODEL DESCRIPTION}

The diurnal-average LLNL 2-D CRT model currently determines the atmospheric distributions of 47 chemically active atmospheric trace constituents in the troposphere and stratosphere (Wuebbles et al., 1991; Kinnison et al., 1994, and Patten, et al. 1994 for a detailed description). The model domain extends from pole to pole, and from the surface to $60 \mathrm{~km}$. This version of the LLNL 2-D CRT model has a horizontal resolution of 5 degrees in latitude and the vertical coordinate corresponds to the logarithm of pressure, with a resolution of $1.5 \mathrm{~km}$. The photochemistry represents the tropospheric and stratospheric interactions of actinic solar flux and the species families $\mathrm{O}_{x}, \mathrm{NO}_{y}, \mathrm{ClO}_{y}, \mathrm{HO}_{y}, \mathrm{CH}_{4}$ and its oxidation products, and $\mathrm{BrO}_{\mathrm{y}}$. The chemical mechanism incorporates 43 transported species and 4 species for which abundance is determined through the assumption of instantaneous equilibrium. There are 106 thermal and 47 photolytic reactions. Source gases present in the model include $\mathrm{NO}_{\mathrm{x}}, \mathrm{N}_{2} \mathrm{O}, \mathrm{CH}_{4}, \mathrm{CO}_{2}, \mathrm{CO}$, the 
chlorine containing compounds $\mathrm{CFC} 11,12,113,114,115, \mathrm{HCFC} 22, \mathrm{CCl}_{4}, \mathrm{CH}_{3} \mathrm{CCl}_{3}, \mathrm{CH}_{3} \mathrm{Cl}$, and the bromine containing compounds $\mathrm{CH}_{3} \mathrm{Br}, \mathrm{CF}_{2} \mathrm{ClBr}$, and $\mathrm{CF}_{3} \mathrm{Br}$. Most of the thermal reaction rate constants were taken from the NASA Panel recommendations provided in JPL Publication 92-20 [DeMore et al., 1992]. Absorption cross section information was assembled from a variety of sources, including JPL 92-20. The continuity equation for each individual species is solved using a variable time step, variable order, implicit technique for solving stiff numerical systems with strict error control.

Polar heterogeneous chemistry is present in this version of the model using climatological fields of polar stratospheric clouds (PSCs) and first order representations of the effects of PSC heterogeneous processes on the gas phase species concentrations. These reactions are:

$$
\begin{aligned}
& \mathrm{ClONO}_{2}(\mathrm{~g})+\mathrm{HCl}(\mathrm{s}) \rightarrow \mathrm{Cl}_{2}(\mathrm{~g})+\mathrm{HNO}_{3}(\mathrm{~s}) \\
& \mathrm{ClONO}_{2}(\mathrm{~g})+\mathrm{H}_{2} \mathrm{O}(\mathrm{s}) \rightarrow \mathrm{HOCl}(\mathrm{g})+\mathrm{HNO}_{3}(\mathrm{~s}) \\
& \mathrm{HOCl}(\mathrm{g})+\mathrm{HCl}(\mathrm{s}) \rightarrow \mathrm{Cl}_{2}(\mathrm{~g})+\mathrm{H}_{2} \mathrm{O}(\mathrm{s}) \\
& \mathrm{NO}_{\mathrm{y}}(\mathrm{g}) \rightarrow \mathrm{HNO}_{3}(\mathrm{~s}) \\
& \mathrm{HNO}_{3}(\mathrm{~s}) \rightarrow \text { Sink (denitrification) }
\end{aligned}
$$

Because a zonally averaged representation of temperature will not capture the existence and persistence of the regions of the stratosphere that fall below the threshold for formation of Type I or Type II aerosol, nitric acid trihydrate and water ice, respectively, and because there are no continuous observations of PSC occurrence and abundance with coverage over the polar vortices, we use the frequency of occurrence of PSCs reported by the SAM II satellite from Figure 3-1 in WMO (1992). This occultation instrument revisits the upper latitudes in both hemispheres on a regular basis throughout the winter and reports the presence or absence of PSC aerosol as a function of time/season and altitude. We use this map coupled with the threshold temperature vs. time map for formation of Type I and Type II PSCs (in Figure 1.7.1-1, from WMO, 1989) to scale proportionately the time constants applied to the PSC reactions above.

Among reactions 1 to 4 , the time constants are assigned in proportion to the laboratory reaction probabilities or sticking coefficients. The assumption is that in the presence of PSCs all the $\mathrm{HCl}$ present will be instantly available for heterogeneous processing. The first order frequency of reaction with any available $\mathrm{ClONO}_{2}$ or $\mathrm{HOCl}$, though, decreases with decreasing residual $\mathrm{HCl}$. This probably underestimates the actual degree and rate of processing, although $\mathrm{HCl}$ values rapidly become small in the model. Denitrification in the southern polar vortex 
occurs at a frequency of $1 / 30$ days scaled by the occurrence frequency of Type II aerosol as predicted by temperatures falling below the Type II formation threshold.

To represent the portion of the $\mathrm{HNO}_{3}$ in the zonal average that is actually frozen out as $\mathrm{NAT}$, the loss processes of gas phase $\mathrm{HNO}_{3}$, photolysis and reaction with $\mathrm{OH}$, are also scaled by a factor of 1 - PSC Type I frequency of occurrence. This first order, linearized approach can not capture the actual situation of processing, recovery, and reprocessing that must actually occur, but is probably adequate to represent the effect of polar processing on the global zonally averaged stratosphere for the purposes of this study.

A representation of heterogeneous reactions that occur on sulfuric acid aerosols are included. These reactions are:

$$
\begin{aligned}
& \mathrm{N}_{2} \mathrm{O}_{5}(\mathrm{~g})\left[+\mathrm{H}_{2} \mathrm{O} \text { in aerosol }\right] \longrightarrow 2 \mathrm{HNO}_{3}(\mathrm{~g}) \\
& \mathrm{ClONO}_{2}(\mathrm{~g})\left[+\mathrm{H}_{2} \mathrm{O} \text { in aerosol }\right] \rightarrow \mathrm{HNO}_{3}(\mathrm{~g})+\mathrm{HOCl}(\mathrm{g})
\end{aligned}
$$

Currently we treated these reactions using the following relationship to calculate the two rate constants for the above cases:

$$
\mathrm{K}=(\mathrm{V})(\gamma)(\text { Surface Area Density), }
$$

parameterized as first order loss processes with rate constants determined by specified surface area density, collision frequency, and reaction probability. Aerosol surface area density $\left(\mu \mathrm{m}^{2}\right.$ $\mathrm{cm}^{-3}$ ) for the reference atmosphere is based on analysis of SAGE II data by Poole, Thomason, and Yue [WMO, 1992]. This distribution is representative of an atmosphere that has not been influenced by a major volcanic eruption. The surface area density distribution varies over altitude $(12-32 \mathrm{~km})$, latitude $\left(90^{\circ} \mathrm{N}-90^{\circ} \mathrm{S}\right)$, and time. The effective collision velocity (V) was fixed at $5200 \mathrm{~cm} \mathrm{~s}^{-1}$ for this study for both species. This is close to the collision theory value for both molecules and does not vary significantly over the small temperature range over which stratospheric aerosol is found. The reaction probability per collision $(\gamma)$ is based on laboratory measurements. For $\mathrm{N}_{2} \mathrm{O}_{5}$ on sulfuric acid aerosols the reaction probability is set to 0.1 and does not have a temperature dependence [WMO, 1991]. The reaction probability for $\mathrm{ClONO}_{2}$ on sulfuric acid aerosols [Hanson et al., 1994] is expressed by: 


$$
\gamma_{2}=10^{(1.86-0.0747 \mathrm{~W})}
$$

Where " $W$ " is the weight percent of the sulfuric acid aerosol defined as:

$$
\mathrm{W}=(\mathrm{T}(0.6246 \mathrm{Z}-14.458)+3565) /(\mathrm{T}(-0.19988)+1.3204 \mathrm{Z}+44.777)
$$

and $\mathrm{T}$ is temperature and $\mathrm{Z}$ is the natural logarithm of the $\mathrm{H}_{2} \mathrm{O}$ partial pressure in mb. This reaction does have a strong temperature dependence and the rate of this reaction will be the largest during winter/spring where the stratospheric temperature is the coldest.

\section{RESULTS of NSA STUDY}

We have investigated NSA formation and loss processes under a large range of conditions. In addition, we have considered the potential implications of a large volcanic eruption like Mt. Pinatubo (15 June 1991), increasing the available surface area for heterogeneous conversion of inactive chlorine.

\section{Review of NSA Heterogeneous Mechanism}

A crucial initial fact to understand is that nitrosyl sulfuric acid (NSA), $\mathrm{NOHSO}_{4}$, has been observed in sulfate aerosol particles in the stratosphere by Farlow et al. [1978]. Other facts about NSA are given in tabular form here:

$\begin{array}{lll}\mathrm{NSA}(\mathrm{s}) & \text { a non-volatile ionic solid } & \mathrm{NO}^{+} \mathrm{HSO}_{4}- \\ \mathrm{NSA}(\mathrm{sa}) & \text { dissolved in } \mathrm{H}_{2} \mathrm{SO}_{4}, \text { wt } \%>80 & \mathrm{NO}^{+}(\mathrm{sa})+\mathrm{HSO}_{4}^{-} \text {(sa) } \\ \mathrm{NSA} \cdot \mathrm{H}_{2} \mathrm{O}(\mathrm{sa}) & \text { dissolved in } \mathrm{H}_{2} \mathrm{SO}_{4}, 60<\mathrm{wt} \%<80 & \mathrm{H}_{2} \mathrm{ONO}+(\mathrm{sa})+\mathrm{HSO}_{4}^{-} \\ \mathrm{NSA} \text { solubility in stratospheric sulfate aerosols } & 1-10 \% \\ \text { Molecules of } \mathrm{H}_{2} \mathrm{SO}_{4} \text { in average sulfate particle } & 10^{8} \\ \text { Molecules of } \mathrm{NOHSO}_{4} \text {, in average sulfate particle } & 10^{6} \text { to } 10^{7} \\ \text { Molecules of } \mathrm{HNO}_{3} \text { in average sulfate particle } & 10^{3} \\ \text { Molecules of } \mathrm{HCl} \text { in average sulfate particle } & 10^{0} .\end{array}$

On the basis of known laboratory reactions, there are many processes that could form NSA in the stratosphere, as gaseous $\mathrm{NO}_{\mathrm{x}}$ species collide with sulfate aerosol particles and are temporarily incorporated in them: 


$$
\begin{aligned}
& \mathrm{NO}(\mathrm{g})+\mathrm{NO}_{2}(\mathrm{~g})+2 \mathrm{H}_{2} \mathrm{SO}_{4}(\mathrm{sa})=2 \mathrm{NOHSO}_{4} \text { (s or sa) }+\mathrm{H}_{2} \mathrm{O}(\mathrm{g}) \\
& 2 \mathrm{NO}_{2}(\mathrm{~g})+2 \mathrm{H}_{2} \mathrm{SO}_{4}(\mathrm{sa})=\mathrm{NOHSO}_{4}(\text { s or sa })+\mathrm{NO}_{2}(\mathrm{~g})+\mathrm{H}_{2} \mathrm{O}(\mathrm{g}) \\
& \mathrm{HONO}(\mathrm{g})+\mathrm{H}_{2} \mathrm{SO}_{4}(\mathrm{sa})=\mathrm{NOHSO}_{4}(\mathrm{sa})+\mathrm{HNO}_{3}(\mathrm{~g}) \\
& \mathrm{HNO}_{3}(\mathrm{~g})+\mathrm{NO}(\mathrm{g})+\mathrm{H}_{2} \mathrm{SO}_{4}(\mathrm{sa})=\mathrm{NOHSO}_{4} \text { (s or sa) }+\mathrm{NO}_{2}+\mathrm{H}_{2} \mathrm{O}(\mathrm{g}) \\
& \mathrm{SO}_{2}(\mathrm{~g})+\mathrm{HNO}_{3}(\text { l or sa })=\mathrm{NOHSO}_{4} \text { (s or sa) }
\end{aligned} .
$$

It is established that hydrogen chloride gas reacts with NSA at room temperature:

$$
\mathrm{HCl}(\mathrm{g})+\mathrm{NOHSO}_{4}(\text { s or } \mathrm{sa})=\mathrm{H}_{2} \mathrm{SO}_{4}(\mathrm{l})+\mathrm{ClNO}(\mathrm{g})
$$

This reaction is a standard laboratory preparation of nitrosyl chloride [Coleman et al., 1939], and it is one step in an industrial process for producing $\mathrm{Cl}_{2}$ [Oblad, 1969]. The catalytic reaction is most simply expressed where $\mathrm{HONO}(\mathrm{g})$ is source of NSA:

$$
\begin{aligned}
& \mathrm{HONO}+\mathrm{H}_{2} \mathrm{SO}_{4}=\mathrm{H}_{2} \mathrm{ONO}^{+}+\mathrm{HSO}_{4}^{-} \\
& \mathrm{H}_{2} \mathrm{ONO}^{+}+\mathrm{HCl}+\mathrm{HSO}_{4}^{-}=\mathrm{H}_{2} \mathrm{O}+\mathrm{CINO}+\mathrm{H}_{2} \mathrm{SO}_{4}
\end{aligned}
$$

$$
\text { Net: } \mathrm{HONO}+\mathrm{HCl}=\mathrm{H}_{2} \mathrm{O}+\mathrm{CINO} \text {. }
$$

where the second step is a concerted reaction in the sulfuric acid solution:

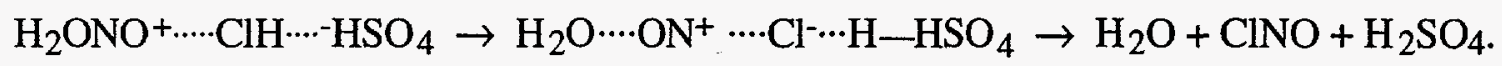

CINO absorbs in the near ultraviolet with breaking of the $\mathrm{Cl}-\mathrm{N}$ bond. Reaction (13) would shift the partitioning of $\mathrm{ClO}_{y}(\mathrm{Cl}+\mathrm{ClO}+\mathrm{HOCl}+\mathrm{ClONO}+\mathrm{HCl})$ toward $\mathrm{Cl}$-containing radical species and temporary $\mathrm{Cl}$ reservoirs, such as $\mathrm{ClONO}_{2}$, and away from $\mathrm{HCl}$. Its importance depends on its magnitude compared to the reaction of $\mathrm{OH}$ with $\mathrm{HCl}$, which also releases $\mathrm{Cl}$.

\section{NSA Model Study at LLNL}

A proper calculation of the NSA abundance (as mentioned above) would require representing the processes of aerosol formation, growth, and loss, as well as the heterogeneous NSA-forming reactions. In this study we have developed a simpler representation of the NSA chemical mechanism for the LLNL 2-D model that examines the potential impact of the NSA formation reactions (8)-(10) coupled with the $\mathrm{ClO}_{y}$ processing reaction (13). For the NSA 
formation reactions we have followed a procedure similar to reactions (6) and (7) on sulfuric acid aerosols. Recently, published laboratory data (Saadstad et al., 1993) suggest that reactions (8) and (9) are limited to the reaction probability (or uptake coefficient) of collision of NO and $\mathrm{NO}_{2}$ with the sulfuric acid aerosol. A static reaction chamber connected to a mass spectrometer was employed to study the adsorption of $\mathrm{NO}$ and $\mathrm{NO}_{2}$ on to cold surfaces of pure ice and liquid/solid $70 \mathrm{wt} \% \mathrm{H}_{2} \mathrm{SO}_{4}$. Under their experimental conditions no significant adsorption could be observed for surface temperatures in the range 193-243 K (stratospheric conditions) and NO/NO 2 partial pressures of $10^{-2}-10^{-5}$ mbar (larger than stratospheric conditions). Based on this study, Saadstad et al (1993), set a upper limit of $5 \times 10^{-5}$ for the reaction probability. Sensitivity calculations for these reactions have been done assuming the following reaction rates:

\begin{tabular}{|c|c|c|c|}
\hline CASE & $\begin{array}{l}\text { Reaction Probability } \\
\text { for: } \\
(\mathrm{NO} \rightarrow \mathrm{NSA})\end{array}$ & $\begin{array}{l}\text { Reaction Probability for: } \\
(\mathrm{HONO} \rightarrow \mathrm{NSA})\end{array}$ & $\begin{array}{l}\text { Solution Phase } \\
\text { Rate Constant for: } \\
\mathrm{HCl}+\mathrm{NSA} \\
\left(\mathrm{cm}^{3} \mathrm{molec}^{-1} \mathrm{~s}^{-1}\right)\end{array}$ \\
\hline Reference & 0.0 & 0.0 & 0.0 \\
$\mathrm{~A}$ & $5.0 \times 10^{-5}$ & $1.0 \times 10^{-2}$ & $1.0 \times 10^{-18}$ \\
$\mathrm{~B}$ & $5.0 \times 10^{-5}$ & $1.0 \times 10^{-2}$ & $1.0 \times 10^{-15}$ \\
$\mathrm{C}$ & $5.0 \times 10^{-5}$ & $1.0 \times 10^{-3}$ & $1.0 \times 10^{-18}$ \\
$\mathrm{D}$ & $5.0 \times 10^{-5}$ & $1.0 \times 10^{-3}$ & $1.0 \times 10^{-15}$ \\
$\mathrm{E}$ & $5.0 \times 10^{-5}$ & $1.0 \times 10^{-1}$ & $1.0 \times 10^{-15}$ \\
$\mathrm{~F}$ & $1.0 \times 10^{-3}$ & $1.0 \times 10^{-1}$ & $1.0 \times 10^{-15}$ \\
\hline
\end{tabular}

We have used the Saadstad reaction probability (cases A-E) for reactions (8) and (9) along with a range of reaction probabilities for reaction (13) (no laboratory measurements available). The solution phase reaction rate between $\mathrm{HCl}$ and $\mathrm{NSA}$ was assumed to be between $10^{-15}$ and $10^{-18}$ as recommended by Johnston (private communication, no laboratory measurements available). The concentration of $\mathrm{HCl}$ in solution is dependent on the following equations:

$$
\begin{aligned}
& \mathrm{HCl}(\mathrm{g})+\text { aerosol } \rightarrow \mathrm{HCl}(\mathrm{l}) \\
& \mathrm{HCl}(\mathrm{l}) \rightarrow \mathrm{HCl}(\mathrm{g})
\end{aligned}
$$

Reaction (14) is assumed to have a reaction probability of unity, while the rate of reaction (15) is derived from experimental data (Hanson et al., 1994) of the Henry Law solubility of $\mathrm{HCl}$ for 
various temperature and $\mathrm{H}_{2} \mathrm{SO}_{4}$ wt \% appropriate under stratospheric conditions. In this study we did not try to model NSA formation reactions (11)-(12). Reaction (11) is probably limited by the solubility of NO. Reaction (12) may be very important right after a volcanic eruption.

Model-derived results when including NSA cases A-F have little effect on the global annual-averaged ozone distribution for a volcanically clean atmosphere. The change in global annual-averaged total ozone is less that $0.1 \%$ for cases A-E. Including case F, changes global annual-averaged total ozone by less than $0.2 \%$. Therefore in all cases studied to date, the effect of NSA on the ambient ozone is negligible.

\section{NSA Mechanism used in a Volcanic Perturbed Atmosphere}

Mt. Pinatubo erupted in June of 1991 - this was the largest volcanic eruption of this century. Following the Mt. Pinatubo eruption, there have been numerous observations of perturbed species distributions that may be caused by heterogeneous reaction on volcanically enhanced sulfuric acid aerosols. The aerosol surface area available following this eruption increased by at least a factor of 30 relative to a volcanically clean background. Local ozone inferred from equatorially measured ozone sonde data in 1992 approached a reduction of $10 \%$ relative to previous years (Grant et al., 1994). In early 1993, over Canada, total ozone was measured by ground based Dobson instruments to be $10 \%$ below a 1988-91 average (Kerr et al., 1993).

Model-derived changes in ozone including reactions (1) and (2) with time-dependent surface area density derived from the SAGE II satellite (personal communication, Larry Thomason, NASA Langley) show global reductions in ozone for 1992 to be $2.5 \%$ below a normal model year (Kinnison et al., 1994). This would not explain the observed data. Including NSA cases A-F, the model-derived 1992 global ozone loss following the Mt. Pinatubo eruption was enhanced slightly for cases A-E. Cases A-D increased the global ozone reduction in 1992 by less than an additional $0.2 \%$. Case $\mathrm{E}$, which included a fast $\mathrm{HONO} \rightarrow \mathrm{NSA}$ formation rate adds an addition reduction of $0.3 \%$. Case $\mathrm{F}$, which includes a large reaction probability for NO $\rightarrow$ NSA formation rate (20 times larger than Saadstad et al., 1993) adds an additional $2.6 \%$ global reduction.

\section{NSA STUDY SUMMARY}


Results suggest that reaction (10) is not important under a wide range of conditions. Reactions (8) and (9), could be very important, especially under volcanically enhanced conditions (case F) - however, if the one and only experimental study of reactions (8) and (9) is correct, there would be little impact on global ozone from NSA following a major volcanic eruption. Including the above NSA mechanism would help to explain (especially case F) the observed low total ozone in 1992 and 1993. These model results need to be validated using a complete treatment of the microphysical processes involved in aerosol formation, growth, and sedimentation.

\section{HETEROGENEOUS PROCESSES AND OZONE TREND}

Having a complete representation of all known important ozone controlling processes will allow us to better understand the extent of the heterogeneous ozone component of the trend. Recently, a preliminary time-dependent model integration from 1980 through present was conducted. In this initial study, heterogeneous reactions 1 through 6 were included (the NSA mechanism was not included at this time). In Figure 1a-b, the model-derived change in column ozone for the equatorial region (Figure 1a) and $62.5^{\circ} \mathrm{N}$ (Figure $1 \mathrm{~b}$ ) are shown. In this scenario variations in solar ultraviolet radiation during the 11-year solar sunspot cycle are influencing stratospheric photochemistry from above. Forcing from below result from the increasing atmospheric concentrations of long-lived trace constituents, such as carbon dioxide, methane, nitrous oxide, several chlorofluorocarbons and other halocarbons. Using the LLNL twodimensional chemical-radiative-transport model of the global atmosphere, we have evaluated the influences of these external forcings on the middle atmosphere. The impact of Mt. Pinatubo (15 June 1991), from enhanced heterogeneous chemical processing on ozone is also included. In the equatorial region (dashed line in Figure la) column ozone decreased by $2 \%$ when including only the effect of increased trace species concentrations. Over half of this change is proportional to including the heterogeneous reactions 1 and 2 described above. The other half is related to standard gas-phase catalytic ozone loss. Including the effect of the 11-year solar sunspot cycle along with the trace gas increase (Figure 1a, solid line) reduces ozone to approximately $2 \%$ in 1986 and shows no trend by 1990 , canceling out the trace gas component. Here the change in column ozone is strongly modulated by the decrease in UV flux from maximum in 1980 to minimum in 1986 period. When the UV flux decreases, the process that primarily forms ozone in the stratosphere, molecular oxygen photolysis decreases, reducing the column amount. Under the same logic, ozone increases as the 11-year cycle again reaches a maximum in 1991. With or without including solar cycle variations, the model-derived equatorial trend is consistent with 
observed data. In 1991, the Mt. Pinatubo volcano erupted increasing the sulfate aerosol loading in the stratosphere. Model-derived changes in the equatorial region are approximately $3 \%$. This underestimates the observed change by a factor of two. In this case, ozone decrease from aerosol heating, changing the mean circulation is probably responsible for the difference. Future model integrations will include the aerosol-heating feedback. In Figure B $\left(62.5^{\circ} \mathrm{N}\right.$ latitude), the effect of solar variability is a minor component of the model-derived trend. Here, the heterogeneous chemical reactions included in the time-dependent integration increase the sensitivity to ozone loss from the increased abundance of chlorine species over the period. However, even when including heterogeneous reactions 5 and 6 on sulfate aerosol, the observed mid-latitude ozone change between 1980 and 1990 is over a factor of two greater at $62.5^{\circ} \mathrm{N}$.

\section{FUTURE DIRECTIONS}

In the process of investigating the model-derived trend in ozone, we found areas where improvements could be made to the dynamical representation of the LLNL 2-D model. We are currently updating this component of the model following the work of Garcia et al., 1992. Following these improvements we will add an addition heterogeneous reaction mechanism based on the work of Burley and Johnston (1992). This heterogeneous process converts $\mathrm{HCl}$, a species that is a reservoir for chlorine in the stratosphere, to CINO, which is photolyzed rapidly, releasing ozone destructive chlorine species. In addition, we will investigate the proposed effect of iodine catalyzed ozone loss (Solomon et al., 1994). Here iodine species are proposed to react with bromine and chlorine radicals at a rate that may be important in understanding the discrepancy between the observed and model-derived mid to high-latitude ozone trend.

Completion of this work will give us the confidence that we are adequately representing the chemical, radiative, and dynamical components of the stratosphere, setting the foundation for investigating the difficult problems of understanding how future changes in trace species abundances may impact the coupled tropospheric-stratospheic chemistry-climate system. 


\section{REFERENCES}

Burley, J. D., and H. S. Johnston, Ionic Mechanisms for Heterogeneous Stratospheric Reactions and Ultraviolet Photo-absorption Cross Sections for $\mathrm{NO}_{2}{ }^{+}, \mathrm{HNO}_{3}$, and $\mathrm{NO}_{3}{ }^{-}$in Sulfuric Acid Solutions. Geophys. Res. Lett. 19, 1359-1362, 1992a.

Burley, J. D., and H. S. Johnston, Nitrosyl Sulfuric Acid and Stratospheric Aerosols. Geophys. Res. Lett. 19, 1363-1366, 1992b.

Coleman, G.H., G.A. Lillis, and G.E. Goheen, Chapter 5 in Inorganic Syntheses, Vol. I, Booth, H.S., Editor, McGraw-Hill, N.Y. 55-59, 1939.

DeMore, W. B., S. P. Sander, D. M. Golden, M. J. Molina, R. F. Hampson, M. J. Kurylo, C. J. Howard, A. R. Ravishankara and C. E. Kolb, Chemical kinetics and photochemical data for use in stratospheric modeling, Evaluation Number 10, JPL Publ. 92-20, Jet Propulsion Lab., Pasadena, Calif., August 15, 1992.

Farlow, N.H., K.G. Snetsinger, D.M. Hayes, H.Y. Lem, and B.M. Trooper, Nitrogen-sulfur compounds in stratospheric aerosols, J. Geophys. Res., 83, 6207-6211, 1978.

Farman, J.C., B.G. Gardiner, and J.D. Shanklin, Large losses of ozone in Antarctica reveal seasonal $\mathrm{CIO}_{\mathrm{X}} / \mathrm{NO}_{\mathrm{X}}$ interaction, Nature, 315, 207-210, 1985.

Garcia, R. R., F. Stordal, S. Solomon, and J. T., Kiehl, A new numerical model of the middle atmosphere, I, Dynamics and transport of tropospheric source gases, J. Geophys. Res., 97, 12967, 1992.

Grant, W. B., E. V. Browell, J. Fishman, V. G. Brackett, R. E. Veiga, D. Nganga, A. Minga, B. Cros, C. F. Butler, M. A. Fenn, C. S. Long, and L. L. Stowe, Aerosol -associated changes in tropical stratospheric ozone following the eruption of Mount Pinatubo, J. Geophys. Res., 99, 8197-8211, 1994.

Hanson, D. R., A. R. Ravishankara, and S. Solomon, Heterogeneous reactions in sulfuric acid aerosols: A framework for model calculations, J. Geophys. Res., in press, 1994.

Hofmann, D. J., and S. Solomon, Ozone destruction through heterogeneous chemistry following the eruption of El Chichon, J. Geophys. Res., 94, 5029-5041, 1989.

Johnston, H., D.E. Kinnison, and D.J. Wuebbles, Nitrogen oxides from high altitude aircraft: an update of potential effects on ozone, J. Geophys. Res., 94, 16351-16363, (Also LLNL UCRL-100714), 1989.

Kerr, J. B., D. I. Wardle, and D. W. Tarasick, Record low ozone values over Canada in early 1993, Geophys. Res. Lett. , 20, 1979-1982, 1993. 
Kinnison, D.E., The effect of trace gases on global atmospheric chemical and physical processes. University of California at Berkeley, Ph.D. Thesis (Also LLNL Report UCRL53903), 1989.

Kinnison, D.E., and D.J. Wuebbles, Future aircraft and potential effects on stratospheric ozone and climate. 42nd Congress of the International Astronautical Federation, Ref.\# IAA-91-736, October 5-11, Montreal (Also LLNL Report UCRL-JC-108035), 1991.

Kinnison, D.E., K.E. Grant, P.S. Connell, D.A. Rotman, and D.J. Wuebbles: The chemical and radiative effects of the Mt. Pinatubo eruption, J. Geophys. Res., 99, 25705-25731, LLNL Report UCRL-JC-108363), 1994.

Oblad, A.G., Kel-Chlor process, Ind. Eng. Chem., 61(7), 23-26, 1969.

Patten, K. O., Jr., P. S. Connell, D. E. Kinnison, D. J. Wuebbles, T. G. Slanger, and L. Froidevaux, Effect of vibrationally excited oxygen on ozone production in the stratosphere, $J$. Geophys. Res., 99, 1211-1224, 1994.

Rodriguez, J.M., M.K.W. Ko, and N.D. Sze, Role of heterogeneous conversion of $\mathrm{N}_{2} \mathrm{O}_{5}$ on sulphate aerosols in global ozone losses, Nature, 352, 134-137, 1991.

Saadstad, O.W., T. Ellermann, and C.J. Nielsen, Geophys. Res. Lett., 20, 1191-1193, 1993.

Solomon, S., R. R. Garcia, and A. R. Ravishankara, J. Geophys., Res., 99, 20491-20499, 1994.

Stolarski, R.S., et al., Total ozone trends deduced from Nimbus 7 TOMS data, Geophys. Res. Lett., 18, 1015-1018, 1991.

Webster, C. R., R. D. May, D. W. Toohey, L. M. Avallone, J. G. Anderson, P. Newman, L. Lait, M. R. Schoeberl, J. W. Elkins, and K. R. Chan, Chlorine chemistry on polar stratospheric cloud particles in the Artic winter, Science, 261, 1130-1133, 1993.

Wuebbles, D.J., D.E. Kinnison, K.E. Grant, and J. Lean, The effect of solar flux variations and trace gas emissions on recent trends in stratospheric ozone and temperature. J. of Geomag. Geoelectr., 43, Suppl., 709-718, 1991.

World Meteorological Organization Global Ozone Research and Monitoring Project-Report No. 16, Atmospheric Ozone: 1985. Three Volumes, NASA, Earth Science and Applications Division, Code EE, Washington, DC., 1986.

World Meteorological Organization, Global Ozone Research and Monitoring Project-Report No., 20, Scientific Assessment of Stratospheric Ozone, Two Volumes. NASA, Earth Science and Applications Division, Code EE, Washington, DC., 1989.

World Meteorological Organization, Global ozone research and monitoring project-Report, No., 25, Scientific Assessment of Ozone Depletion: 1991. NASA, Earth Science and Applications Division, Code EE, Washington, DC., 1992. 

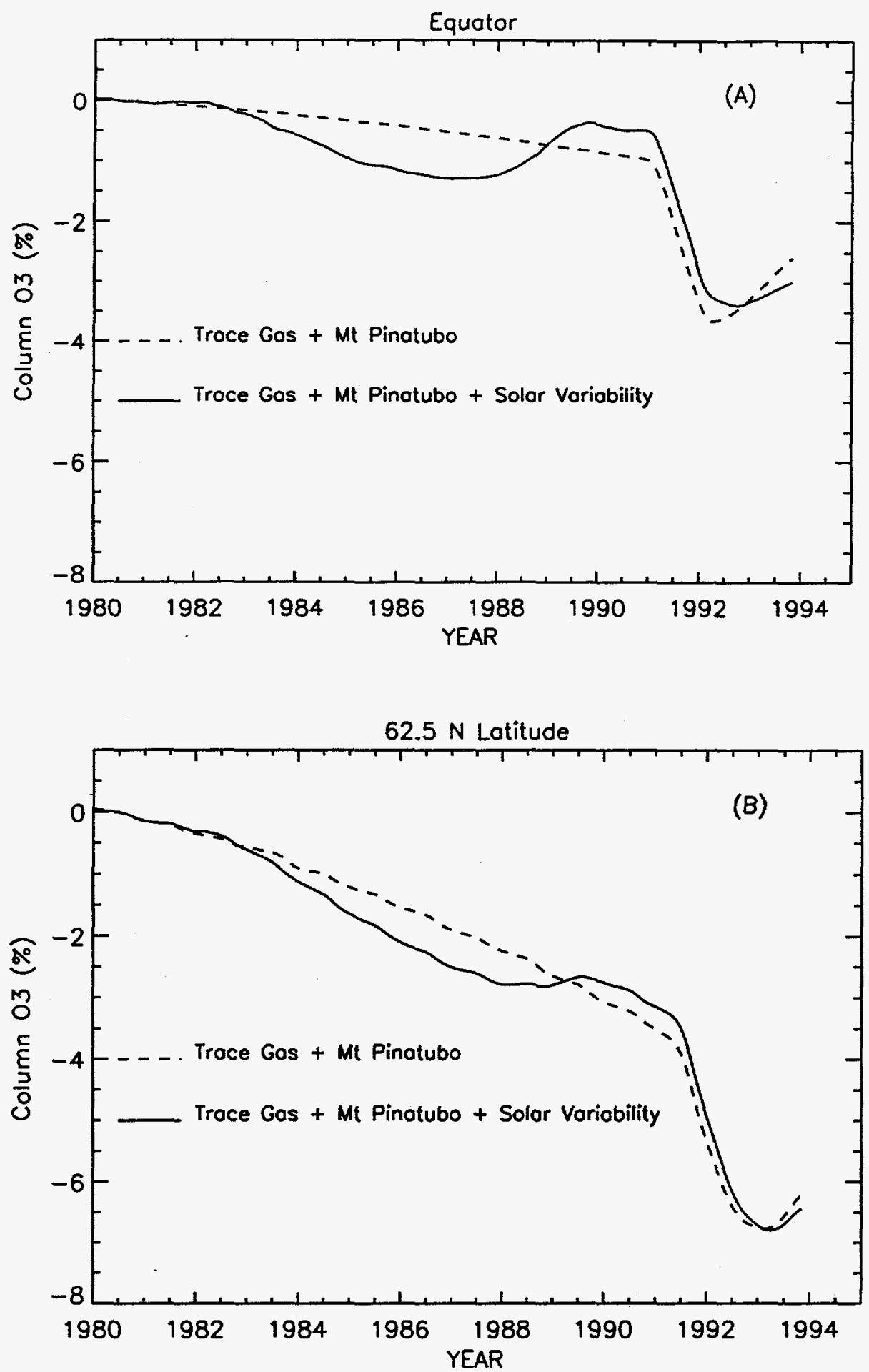

Figure 1

Model-derived percent change in column ozone at the equator (A) and $62.5 \mathrm{~N}$ (B). The dashed line includes increases in observed trace gas abundances at the surface between 1980 and present (e.g., $\mathrm{N}_{2} \mathrm{O}, \mathrm{CO}_{2}, \mathrm{CH}_{4}$, and $\mathrm{CFCs}$ ). The solid line includes both trace gas increases and the effect of the 11-year solar sunspot cycle modulation of ozone. Both Figures A and B are relative to 1980 . 


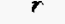

$r$

.

. 